\title{
A comparative study on economics of milk production among self-help group members and non-members in Rajasthan
}

\author{
Ritu Rathore $^{1}$, Ravinder Malhotra $^{1}$, Udita Chaudhary $^{1}$ and Rajendra Jangid ${ }^{2}$
}

Received: 21 April 2020 / Accepted: 14 September 2020 / Published online: 27 December 2020

(c) Indian Dairy Association (India) 2020

\begin{abstract}
The present study was undertaken to determine the cost and returns from milk production across different herd size categories of self-help group members and non-members. Primary data from 160 self-help group members and 160 non-members were collected from Baran and Jhalawar district of Rajasthan during 2018-19. Its analysis showed that for members, overall average cost per litre of milk production for buffalo, local milch cow and crossbred was Rs. 32.81, Rs. 37.1 and Rs. 29.38, respectively, while, for non-members, the corresponding figures were Rs. 32.6, Rs. 37.47 and Rs. 30.25, respectively. Net return per litre of milk production was positive for buffalo and crossbred cow, while it was negative for local milch cow. Net return for all types of animals was found to be higher for members compared to the non-members, and it was found to increase with the increase in herd size.
\end{abstract}

Keywords: Cost, Returns, Milk, Production, Self-help groups

\section{Introduction}

Livestock sector plays a very important role in Indian economy. It contributes $4.11 \%$ to the Gross Domestic Product of India (Livestock Census, 2019-20). Its contribution in total agriculture GDP is $25.6 \%$ (Livestock Census, 2019-20). Currently, dairy is the

'DES\&M, ICAR-National Dairy Research Institute, Karnal-132 001, India

${ }^{2}$ Swami Keshwanand Rajasthan Agricultural University, Bikaner-334 006, India

Ritu Rathore $(\square)$

DES\&M, ICAR-National Dairy Research Institute, Karnal-132 001, India

Email: riturathore1012@gmail.com top-ranking commodity in India in value terms. About one third of rural people are dependent upon dairying and $75 \%$ of rural households own, on an average, two to four animals (Livestock Census, 2019-20). This sector not only provides livelihood to the rural community but also generates gainful employment. Dairying provides a source of regular income, which minimizes risks to household's total income. According to Economic Survey (201920 ), livestock has become a very important secondary source of income for a number of rural households. Some previous studies indicate that areas where dairy is well developed have less incidence of farmer's suicide. Though livestock has a significant role to play in economic and socio-cultural wellbeing of human life, especially in rural households, but this sector did not receive the financial attention it deserved. Farmers do not get adequate amount of credit for investment in animal rearing. Hence, one key tool to overcome this problem could be the self-help group based microfinance. Self-help groups have evolved as the world's largest and most successful programs of group-based microfinance institution for the rural poor. They provide easy and affordable banking services to the poor and marginalized sections of society to secure inputs like credit and other services. This credit facility is not limited to agriculture but also extended to dairy farming. SHG members borrow money from their respective groups for various purposes, like as consumption loan, or to run economic activities and small businesses, etc. (Borbora and Mahanta, 2001; Awasthi et al. 2001; Puhazhendi and Batadya, 2002). Madheswaran and Dharmadhikary (2001) reported that members borrow from SHGs mainly for the purpose of dairy farming. Loan taken for dairy farming improves the farmers' standard of living by increasing income from milk production.

Rajasthan is India's second largest producer of milk after Uttar Pradesh. It possesses $10.59 \%$ of the total livestock population of the country and contributes to almost $12.60 \%$ of the milk production (20 th Livestock Census, 2019). Income from livestock averages $22.50 \%$ of the total household income, whereas in arid region the contribution of livestock sector is even more than $50 \%$ of the total household income (Department of Animal husbandry, Govt. of Rajasthan, 2017-18). Out of a total of 83054 SHGs in the state, 69918 SHGs $(84.18 \%)$ are working well (Rajasthan Grameen Aajeevika Vikas Parishad). Hence, after analyzing the importance of livestock sector and role of SHGs in 
uplifting livestock sector, present study was undertaken in Rajasthan with an objective to compare economics of milk production among different herd size categories of SHG members and non-members.

\section{Materials and Methods}

\section{Selection of study area}

To conduct the study, Rajasthan state was selected purposively. Out of the total 33 districts of Rajasthan, two districts, namely Baran and Jhalawar, which have the highest number of dairy selfhelp groups in the state were selected purposively (RAJEEVIKA). Two blocks were selected randomly from each district and from each block 20 SHGs were selected randomly. Anta and Baran were the two blocks selected from Baran district and Pirawa and Bakani were selected from Jhalawar district. Hence, a predetermined sample of 80 women dairy self-help groups which have already completed at least two years of experience since their inception were selected randomly assuming that the benefits of participation in self-help groups are fairly pronounced in two years. For the study, dairy self-help groups were those which have already received dairy loan and whose activity is specified as dairy farming.

Two members were selected randomly from each of the selected dairy SHGs. Thus, 80 members from each district and a total of 160 SHG members from both the districts were selected. Besides, 160 non-members were also selected from the same village for comparative analysis. Individuals who were not member of any SHG and come from the same socio-economic status as members in terms of number of animals and land holding were selected as non-members.

\section{Dataset description}

Primary data from 320 respondents were collected for the study by conventional survey method on a well-structured and pretested schedule through personal interview. Data on the quantity and prices of various inputs used in dairy farming, investment on fixed assets, feed and fodder fed to the dairy animals, prevailing market price of the feed and fodder, labour used in different activities of milk production, wage rates, veterinary and miscellaneous expenses, milk production from individual animal, quantity of milk sold, purchase and sale of animals and details of breeding animals etc. were collected from the study area.

\section{Analytical framework}

\section{Cost of milk production}

\section{Fixed cost}

Fixed cost included the cost of durable assets like farm inventory, cattle inventory, farm equipments etc. and was taken care of by charging depreciation on purchase cost. It also included rental value of land and interest on fixed capital investment. Capital recovery cost method (CRC) was used to calculate depreciation. The cost item interest on fixed capital does not need to be calculated separately when CRC approach is followed.

The CRC method is defined as the annual payment that will repay the cost of fixed input over the useful life of input and provide an economic rate of return on investment.

\section{Capital recovery cost of farm inventory and equipments}

The formula for estimation of CRC for farm inventory and equipments is as follows:

$R=Z\left[\frac{(1+r)^{n} r}{(1+r)^{n}-1}\right]$

Where,

$\mathrm{R}=$ Capital recovery cost

$\mathrm{Z}=$ Initial value of the capital asset

$\mathrm{r}=$ Interest rate

$\mathrm{n}=$ Useful life of the assets

Total CRC was calculated and was later apportioned to the individual animals using Standard Animal Units (SAUs).

\section{Capital recovery cost of milch animals}

Formula for CRC estimation of milch animals is same as that of above but the value of ' $n$ ' has to be ascertained differently for each animal. Like different types of fixed assets, useful life of milch animals also varies with the type of animal. Generally, the useful productive life of crossbred is taken as 8 years ( 5 calvings) and of local cow and buffalo as 10 years ( 6 calvings). But, these cannot be used as such because using the value of the animal at the time of birth as initial value for estimation of capital recovery cost won't be appropriate. The value of the animal varies with wet-dry status, pregnancy (pregnant or Non-pregnant), order of lactation, stage of lactation, etc. Hence, the estimation of CRC based on the current value of milch animal is appropriate rather than considering their initial value. When current value is taken into account, ' $n$ ' has to be worked out as the length of remaining productive life.

$n=[$ maximum calving -1$) \times$ intercalving period $]-[$ (number of calving done

value of animals as the salvage value is quite high at the end of productive life. 


\section{Variable cost}

Variable cost included four items i.e. feed and fodder cost, labour cost, veterinary cost and miscellaneous expenditure.

\section{Feed and fodder cost}

Feed and Fodder cost included the cost of feeding dry fodder, green fodder and concentrates. In case of purchased feed and fodder, the cost was worked out as product of quantity fed to animal and purchase price of respective feed. In case of homegrown feed and fodder, the relevant prices were the farm-harvest prices. For certain types of fodder, especially cultivated green fodder, where farm-harvest prices were not available, the imputed value of crop was taken as the prevailing price of standing crop in the village. In case the animal was fed with collected grass and tree leaves from the common property resources, its imputed value was their expected sale price and was accounted for estimating the cost. If the concentrate was homemade then the weighted average of prices of all the ingredients was taken to ascertain the price of concentrate.

\section{Labour cost}

Labour was differentiated into hired labour and own labour. One man day consisted of 8 hours for estimation of labour cost in case of women labourers. Total time spent on different dairy activities was calculated and converted to man days. The cost of grazing of animals was also included in labour cost.

\section{Veterinary and miscellaneous costs}

Veterinary expenses included cost of artificial insemination (AI), natural services, vaccination, medicines, fee of veterinary doctor and other related expenses. Miscellaneous expenditure included expenses on repair of fixed assets, water and electricity charges, insurance premium and any other incidental charges. These being joint costs, apportionment of the same was done based on SAUs.

\section{Apportionment of joint costs and standard animal unit}

There are several items in the dairy farm households, such as the cattle sheds, dairy equipment and machinery that cater to the entire animal herd on the farm rather than being specific to individual animal. The cost incurred on these items is joint costs. Similarly, the land rent, interest on capital funds, labour cost, recurring expenses on repairs, etc. are all joint costs and hence need to be apportioned on some scientific basis.

The animal herd comprised of animals of different types (indigenous cows, crossbred cattle and buffaloes), sex (male, female) and age-groups. Considering that the extent of utilization of fixed assets and labour utilization is different across these categories of animals, apportionment of joint costs attributable to these inputs becomes necessary. For this purpose the different categories of animals were converted into homogenous animal units by using certain conversion coefficients known as Standard Animal Units (SAUs) by Sirohi et al. (2015). As Rajasthan falls in western region, Standard Animal Units for western region presented in Table 1 were used.

\section{Other cost concepts}

Gross cost, net cost, gross returns, net returns and costs per litre of milk were calculated using the following formulae:

Gross cost: It was obtained by adding all the cost components including fixed and variable costs.

Gross cost $=$ Total fixed cost + Total variable cost

Net cost: It was worked out by deducting the imputed income earned through dung from the gross cost.

Net cost $=$ Gross cost " Value of dung

Gross returns: Gross returns were obtained by multiplying milk yield of an individual milch animal with respective prevailing prices in the study area.

Gross returns $=$ Quantity of milk $\times$ Market price of milk

Net returns: Net return was calculated by subtracting net cost from gross returns

Net returns $=$ Gross returns - Net cost

\section{Results and Discussion}

\section{Socio-economic profiling of members versus non-members}

The data obtained through primary survey covered a wide range of information on personal and household characteristics of members and non-members. Table 2 presents socio-economic profile of members and non-members. As shown in the Table, average size of land holding for members was found to be 0.93 ha as compared to 1.02 ha for non-members. Average education level of non-members $(0.78)$ was slightly higher than that of the members (0.56), i.e., non-members were more educated than members. Total herd size in terms of standard animal unit in case of member households was slightly higher than that of nonmember households. On an average, it was found to be 6.63 in case of member households as compared to 6.13 for non-member households. This implies that herd size for member and nonmember households was comparable. Members were more experienced in dairy (12.58 years) as compared to non-members ( 9.18 years).

Non-members were relatively younger than the members albeit by only a year. Average age of members was approximately 35 years compared to 34 years for non-members. Average yearly 
income in case of member households was Rs. 60532 compared to Rs. 76031 for non-member households.

\section{Composition of dairy animals among members and non-members}

Average size of herd in terms of standard animal unit is presented in Table 3. Results showed that average herd size in terms of standard animal unit, for members and non-members were 6.63 and 6.13, respectively. Members possessed higher number of animals compared to the non-members. In the sample households, number of buffalo was more than that of local cow and crossbred. For members, number of buffalo, local cow and crossbred in terms of standard animal unit were 3.09, 1.71 and 1.84, respectively, while for non-members, the corresponding figures were $3,1.58$ and 1.55 , respectively.

\section{Cost and returns of milk production - Buffalo}

Per day average cost and returns of milk production per milch buffalo were calculated across different herd size categories of the SHG members and non-members and results are being presented in Table 4. It is clear from the table that on an average, total fixed cost for member groups was Rs. 27.49 which is comparable to the total fixed cost for non-members (Rs. 27.98). Total fixed cost was higher for medium and large herd size categories as compared to small herd size category, in case of both members and non-members. The overall average feed and fodder cost for members and non-members was Rs. 142.05 and Rs. 140.09 per animal per day, respectively. The breakup of cost components revealed that out of total gross cost, total fixed cost constituted $11.6 \%$ for members and $12.31 \%$ for non-members, while total variable cost contributed $88.40 \%$ and $87.69 \%$ of gross cost for member and non-member groups, respectively. Total variable cost comprised major share of gross cost. Share of average feed and fodder cost was $67.77 \%$ and $70.32 \%$ of total variable cost for members and non-members, respectively, while labour cost contributed $30.77 \%$ and $28.1 \%$ of total variable cost for members and non-members, respectively. Share of miscellaneous cost in total variable cost for both members $(1.46 \%)$ and non-members $(1.58 \%)$ was very less. In case of both members and non-members, share of feed and fodder cost increased with the increase in herd size, while that of labour cost decreased with the increase in herd size. Both the costs were found to be low in case of non-members as compared to members. Net cost per animal per day was Rs. 230.93 for members and Rs. 22.36 for nonmembers. Net cost per litre of milk production was Rs. 32.81 per animal per day for members and Rs. 32.6 per animal per day for non-members and it was found to decrease with the increase in herd size. This indicates that cost per litre of milk production was

Table 1 Standard Animal Units for western region in India

\begin{tabular}{llll}
\hline Animal type & Crossbred & Local Cow & Buffalo \\
\hline Adult male $(\geq 3$ years) & 0.87 & 0.72 & 0.82 \\
Adult female ( $\geq 3$ years) & 1.18 & 1.00 & 1.22 \\
Young stock male $(<1$ year) & 0.39 & 0.36 & 0.40 \\
Young stock female $(<1$ year) & 0.37 & 0.35 & 0.38 \\
Young stock male $(>=1$ year) & 0.55 & 0.40 & 0.46 \\
Young stock female ( $>=1$ year) & 0.42 & 0.38 & 0.42 \\
Heifer & 0.51 & 0.40 & 0.48 \\
\hline
\end{tabular}

Table 2 Socio-economic profiling of members versus non-members

\begin{tabular}{llll}
\hline Variables & Unit & Average value & Non-member \\
\cline { 3 - 4 } & & Member & 1.02 \\
\hline Land holding & Acre & 0.93 & 0.78 \\
Education level of respondent & Categorical variable & 0.56 & 6.13 \\
Total herd size & Standard animal unit & 6.63 & 9.18 \\
Experience in dairy & Years & 12.58 & 33.64 \\
Age of respondent & Years & 34.96 & 76031 \\
Yearly income & Rupees & 60532 & \\
\hline
\end{tabular}

Table 3 Herd composition among members and non-members

(Standard Animal Unit)

\begin{tabular}{lll}
\hline Type of animal & Members & Non-members \\
\hline Buffalo & 3.09 & 3.00 \\
Local Cow & 1.71 & 1.58 \\
Crossbred & 1.84 & 1.55 \\
Overall & 6.63 & 6.13 \\
\hline
\end{tabular}


relatively higher for members compared to the non-members. Meena (2008) in Alwar district and Devi and Jain (2011) in Jaipur district of Rajasthan also found similar results.

Average milk production per milch buffalo for members was 7.04 litre per day, while for non-members, the corresponding figure was 6.79 litre per day. Average returns from milk for members and non-members were Rs. 258.27 and Rs. 246.14 per animal per day, respectively. Income from dung was Rs. 6.16 per animal per day for members and Rs. 5.85 per animal per day for non-members. Net return per animal was calculated as Rs. 27.33 per day for members and Rs. 24.78 per day for non-members. Category-wise results for both members and non-members showed that net return increased as herd size increased. Net return per litre of milk production was Rs. 3.88 per animal per day for members and Rs. 3.65 per animal per day for non-members. This indicates that

members are getting higher returns compared to the non-members. These findings are similar to the other researchers (Meena, 2008; Devi and Jain, 2011). Category-wise breakup showed that net return per litre of milk production for small, medium and large herd size categories of members was Rs. 3.09, Rs. 3.46 and Rs. 4.89 per animal per day, respectively, while with respect to nonmembers, net return per litre of milk production for small, medium and large herd size categories was Rs. 2.98, Rs. 3.23 and Rs. 4.33 per animal per day, respectively. This implies that in case of both members and non-members, net return per litre increase with the increase in herd size. The reason being cost of milk production decreases with the increase in herd size.

\section{Cost and returns of milk production - Local milch cow}

Table 4 Cost and returns of milk production for milch buffalo across different herd size categories of members and non-members (per animal per day)

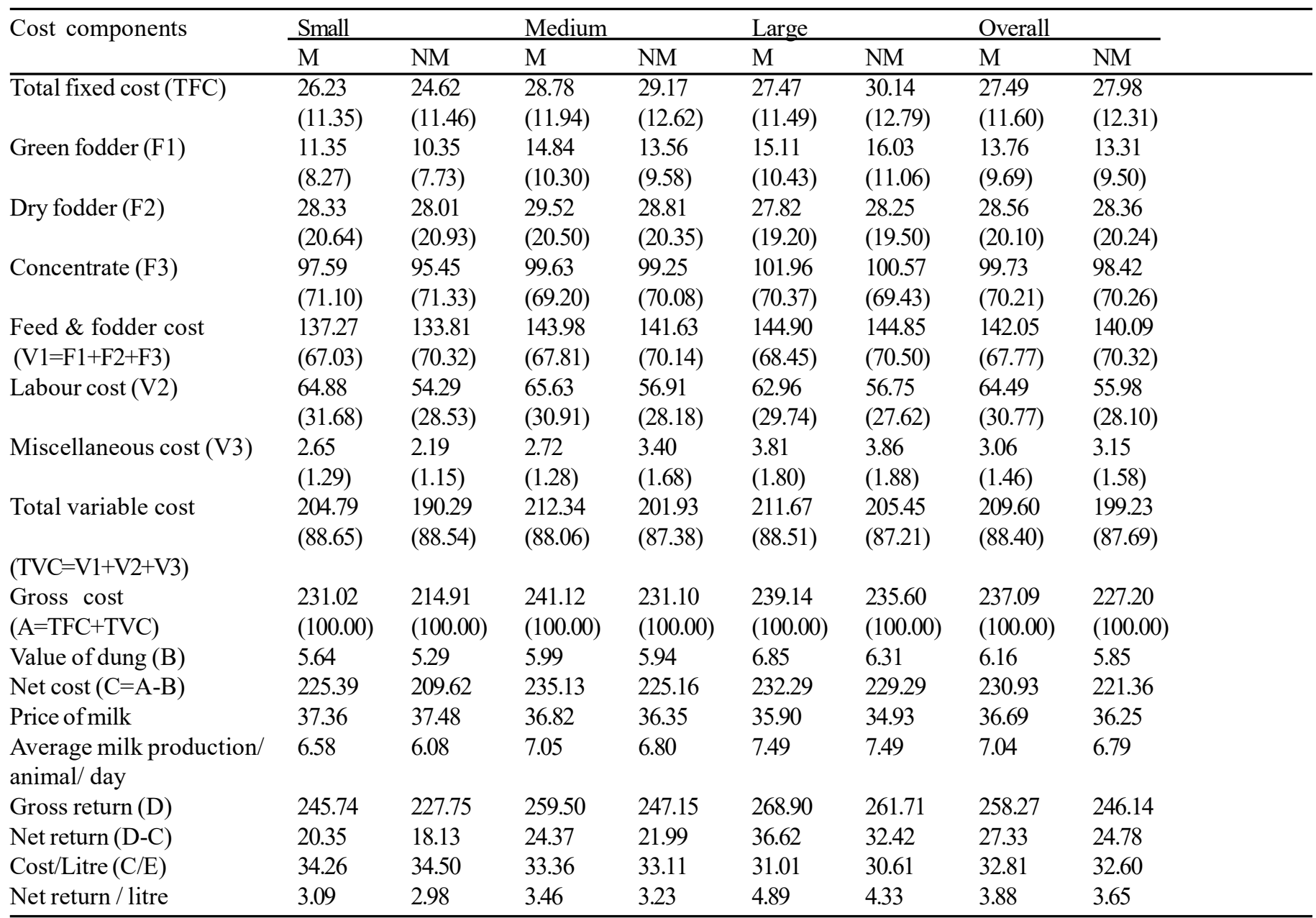

Note: (1) M-Member, NM-Non-member (2) Figures in parenthesis in the feed and fodder cost, labour cost and miscellaneous cost rows denote their respective shares in the total variable cost. (3) Figures in parenthesis in the green fodder, dry fodder and concentrate rows denote their respective shares in the feed and fodder cost. 
Cost and returns of milk production for local milch cow are presented in Table 5. Perusal of data in table shows that total fixed cost for members and non-members was Rs. 22.74 and Rs. 23.66 per animal per day, respectively, while, total variable cost per animal was Rs. 130.42 per day for members and Rs. 123.29 per day for non-members. Total feed and fodder cost per animal per day was Rs. 92.83 for members and Rs. 92.64 for non-members, which contributed $71.18 \%$ and $75.14 \%$ of total variable cost in case of members and non-members, respectively. Feed and fodder cost contributed highest share in total variable cost. This finding is in line with the findings of Mian et al. (2007). Labour cost contributed $26.95 \%$ and $22.78 \%$ of total variable cost for members and non-members, respectively. Contribution of miscellaneous cost in total variable cost was very less in case of both members $(1.87 \%)$ and non-members $(2.07 \%)$. Hence, by including all these costs, gross cost per local milch cow was estimated as Rs. 153.16 per day for members and Rs. 146.95 per day for non-members.
Table further reveals that average milk production from a local milch cow was 3.97 litre per day and 3.78 litre per day for members and non-members, respectively. Return from dung and milk for member households was Rs. 5.77 and Rs. 148.88 per animal per day, respectively, while for non-members, the corresponding figures were Rs. 5.28 and Rs. 141.67 per animal per day, respectively. Overall return per litre of milk production from local milch cow was calculated as Rs. 0.37 in case of member household, while for non-members, the corresponding figure was worked out to be negative and the loss was calculated as Rs. 0.40. Mankar (2003) and Desai (2005) also found the similar results. Categorywise results showed that only medium and large herd size categories of members and large herd size category of nonmembers were having positive return, while other categories had negative return from local cow rearing. This implies that rearing local milch cow alone is not profitable for both members and non-members.

Table 5 Cost and returns of milk production for local milch cow across different herd size categories of members and non-members (per animal per day)

\begin{tabular}{|c|c|c|c|c|c|c|c|c|}
\hline \multirow[t]{2}{*}{$\overline{\text { Cost components }}$} & \multicolumn{2}{|l|}{ Small } & \multicolumn{2}{|l|}{ Medium } & \multicolumn{2}{|l|}{ Large } & \multicolumn{2}{|l|}{ Overall } \\
\hline & $\bar{M}$ & NM & $\mathrm{M}$ & NM & $\bar{M}$ & NM & $\mathrm{M}$ & NM \\
\hline Total fixed cost (TFC) & $\begin{array}{l}21.02 \\
(14.00)\end{array}$ & $\begin{array}{l}19.52 \\
(13.89)\end{array}$ & $\begin{array}{l}23.94 \\
(15.31)\end{array}$ & $\begin{array}{l}25.12 \\
(16.81)\end{array}$ & $\begin{array}{l}23.28 \\
(15.21)\end{array}$ & $\begin{array}{l}26.34 \\
(17.46)\end{array}$ & $\begin{array}{l}22.74 \\
(14.85)\end{array}$ & $\begin{array}{l}23.66 \\
(16.10)\end{array}$ \\
\hline Green fodder $(\mathrm{F} 1)$ & $\begin{array}{l}7.90 \\
(9.01)\end{array}$ & $\begin{array}{l}7.21 \\
(8.23)\end{array}$ & $\begin{array}{l}8.13 \\
(8.60)\end{array}$ & $\begin{array}{l}8.95 \\
(9.50)\end{array}$ & $\begin{array}{l}8.16 \\
(8.48)\end{array}$ & $\begin{array}{l}8.65 \\
(9.00)\end{array}$ & $\begin{array}{l}8.06 \\
(8.69)\end{array}$ & $\begin{array}{l}8.27 \\
(8.93)\end{array}$ \\
\hline Dry fodder $(\mathrm{F} 2)$ & $\begin{array}{l}22.47 \\
(25.63)\end{array}$ & $\begin{array}{l}21.47 \\
(24.49)\end{array}$ & $\begin{array}{l}23.79 \\
(25.16)\end{array}$ & $\begin{array}{l}22.61 \\
(24.01)\end{array}$ & $\begin{array}{l}24.28 \\
(25.22)\end{array}$ & $\begin{array}{l}25.20 \\
(26.23)\end{array}$ & $\begin{array}{l}23.51 \\
(25.33)\end{array}$ & $\begin{array}{l}23.09 \\
(24.93)\end{array}$ \\
\hline Concentrate (F3) & $\begin{array}{l}57.30 \\
(65.36)\end{array}$ & $\begin{array}{l}58.97 \\
(67.28)\end{array}$ & $\begin{array}{l}62.62 \\
(66.24)\end{array}$ & $\begin{array}{l}62.62 \\
(66.49)\end{array}$ & $\begin{array}{l}63.84 \\
(66.31)\end{array}$ & $\begin{array}{l}62.25 \\
(64.77)\end{array}$ & $\begin{array}{l}61.26 \\
(65.99)\end{array}$ & $\begin{array}{l}61.28 \\
(66.15)\end{array}$ \\
\hline $\begin{array}{l}\text { Feed \& fodder cost } \\
(\mathrm{V} 1=\mathrm{F} 1+\mathrm{F} 2+\mathrm{F} 3)\end{array}$ & $\begin{array}{l}87.67 \\
(67.88)\end{array}$ & $\begin{array}{l}87.65 \\
(72.41)\end{array}$ & $\begin{array}{l}94.54 \\
(71.42)\end{array}$ & $\begin{array}{l}94.18 \\
(75.75)\end{array}$ & $\begin{array}{l}96.28 \\
(74.22)\end{array}$ & $\begin{array}{l}96.10 \\
(77.19)\end{array}$ & $\begin{array}{l}92.83 \\
(71.18)\end{array}$ & $\begin{array}{l}92.64 \\
(75.14)\end{array}$ \\
\hline Labour cost (V2) & $\begin{array}{l}39.30 \\
(30.43)\end{array}$ & $\begin{array}{l}31.41 \\
(25.95)\end{array}$ & $\begin{array}{l}35.62 \\
(26.91)\end{array}$ & $\begin{array}{l}27.29 \\
(21.95)\end{array}$ & $\begin{array}{l}30.54 \\
(23.54)\end{array}$ & $\begin{array}{l}25.57 \\
(20.54)\end{array}$ & $\begin{array}{l}35.15 \\
(26.95)\end{array}$ & $\begin{array}{l}28.09 \\
(22.78)\end{array}$ \\
\hline $\begin{array}{l}\text { Miscellaneous cost } \\
\text { (V3) }\end{array}$ & $\begin{array}{l}2.18 \\
(1.69)\end{array}$ & $\begin{array}{l}1.98 \\
(1.64)\end{array}$ & $\begin{array}{l}2.21 \\
(1.67)\end{array}$ & $\begin{array}{l}2.87 \\
(2.31)\end{array}$ & $\begin{array}{l}2.91 \\
(2.25)\end{array}$ & $\begin{array}{l}2.82 \\
(2.27)\end{array}$ & $\begin{array}{l}2.44 \\
(1.87)\end{array}$ & $\begin{array}{l}2.56 \\
(2.07)\end{array}$ \\
\hline $\begin{array}{l}\text { Total variable cost } \\
(\mathrm{TVC}=\mathrm{V} 1+\mathrm{V} 2+\mathrm{V} 3)\end{array}$ & $\begin{array}{l}129.15 \\
(86.00)\end{array}$ & $\begin{array}{l}121.04 \\
(86.11)\end{array}$ & $\begin{array}{l}132.38 \\
(84.69)\end{array}$ & $\begin{array}{l}124.34 \\
(83.19)\end{array}$ & $\begin{array}{l}129.73 \\
(84.79)\end{array}$ & $\begin{array}{l}124.49 \\
(82.54)\end{array}$ & $\begin{array}{l}130.42 \\
(85.15)\end{array}$ & $\begin{array}{l}123.29 \\
(83.90)\end{array}$ \\
\hline $\begin{array}{l}\text { Gross cost } \\
(\mathrm{A}=\mathrm{TFC}+\mathrm{TVC})\end{array}$ & $\begin{array}{l}150.17 \\
(100.00)\end{array}$ & $\begin{array}{l}140.56 \\
(100.00)\end{array}$ & $\begin{array}{l}156.31 \\
(100.00)\end{array}$ & $\begin{array}{l}149.46 \\
(100.00)\end{array}$ & $\begin{array}{l}153.01 \\
(100.00)\end{array}$ & $\begin{array}{l}150.83 \\
(100.00)\end{array}$ & $\begin{array}{l}153.16 \\
(100.00)\end{array}$ & $\begin{array}{l}146.95 \\
(100.00)\end{array}$ \\
\hline Value of dung (B) & 5.46 & 5.15 & 5.87 & 5.08 & 5.98 & 5.62 & 5.77 & 5.28 \\
\hline $\operatorname{Net} \operatorname{cost}(C=A-B)$ & 144.71 & 135.41 & 150.44 & 144.38 & 147.03 & 145.21 & 147.39 & 141.67 \\
\hline Price of milk & 38.88 & 38.37 & 37.65 & 37.13 & 35.89 & 35.72 & 37.48 & 37.08 \\
\hline $\begin{array}{l}\text { Average milk production/ } \\
\text { animal/ day }\end{array}$ & 3.38 & 3.18 & 4.05 & 3.84 & 4.49 & 4.32 & 3.97 & 3.78 \\
\hline Gross return (D) & 131.39 & 122.10 & 152.46 & 142.60 & 161.16 & 154.27 & 148.88 & 140.16 \\
\hline Net return (D-C) & -13.32 & -13.31 & 2.02 & -1.77 & 14.13 & 9.06 & 1.49 & -1.51 \\
\hline Cost/Litre (C/E) & 42.83 & 42.55 & 37.15 & 37.60 & 32.75 & 33.62 & 37.10 & 37.47 \\
\hline Net return / litre & -3.94 & -4.18 & 0.50 & -0.46 & 3.15 & 2.10 & 0.37 & -0.40 \\
\hline
\end{tabular}

Note: (1) M-Member, NM-Non-member (2) Figures in parenthesis in the feed and fodder cost, labour cost and miscellaneous cost rows denote their respective shares in the total variable cost.

(3) Figures in parenthesis in the green fodder, dry fodder and concentrate rows denote their respective shares in the feed and fodder cost. 
Table 6 Cost and returns of milk production for crossbred milch cow across different herd size categories of members and nonmembers (per animal per day)

\begin{tabular}{|c|c|c|c|c|c|c|c|c|}
\hline \multirow[t]{2}{*}{ Cost components } & \multicolumn{2}{|l|}{ Small } & \multicolumn{2}{|l|}{ Medium } & \multicolumn{2}{|l|}{ Large } & \multicolumn{2}{|l|}{ Overall } \\
\hline & M & $\mathrm{NM}$ & M & NM & M & NM & M & NM \\
\hline \multirow[t]{2}{*}{ Total fixed cost (TFC) } & 24.78 & 23.45 & 27.81 & 28.90 & 26.95 & 29.42 & 26.51 & 27.26 \\
\hline & $(10.41)$ & $(10.29)$ & (11.67) & $(12.76)$ & $(11.08)$ & $(12.28)$ & $(11.05)$ & $(11.78)$ \\
\hline \multirow[t]{2}{*}{ Green fodder (F1) } & 11.00 & 10.47 & 14.35 & 14.35 & 16.42 & 16.81 & 13.92 & 13.88 \\
\hline & (8.80) & (8.16) & $(10.78)$ & $(10.93)$ & $(10.91)$ & $(11.24)$ & $(10.22)$ & $(10.18)$ \\
\hline \multirow[t]{2}{*}{ Dry fodder (F2) } & 28.55 & 28.64 & 29.83 & 29.02 & 29.65 & 30.74 & 29.34 & 29.46 \\
\hline & $(22.85)$ & $(22.31)$ & $(22.40)$ & $(22.10)$ & (19.69) & $(20.56)$ & $(21.54)$ & $(21.60)$ \\
\hline \multirow[t]{2}{*}{ Concentrate (F3) } & 85.39 & 89.26 & 88.97 & 87.91 & 104.49 & 101.96 & 92.95 & 93.05 \\
\hline & $(68.35)$ & $(69.53)$ & $(66.82)$ & $(66.96)$ & $(69.40)$ & $(68.20)$ & $(68.24)$ & $(68.22)$ \\
\hline Feed \& fodder cost & 124.94 & 128.38 & 133.15 & 131.28 & 150.56 & 149.51 & 136.22 & 136.39 \\
\hline$(\mathrm{V} 1=\mathrm{F} 1+\mathrm{F} 2+\mathrm{F} 3)$ & (58.58) & $(62.80)$ & $(63.26)$ & $(66.42)$ & $(69.59)$ & $(71.11)$ & $(63.84)$ & $(66.83)$ \\
\hline Labour cost (V2) & \multicolumn{2}{|c|}{$85.56(40.11)$} & \multicolumn{2}{|c|}{$73.78(36.10)$} & \multicolumn{2}{|c|}{ 74.43(35.36) } & \multicolumn{2}{|c|}{ 62.92(31.84) } \\
\hline $61.47(28.41)$ & \multicolumn{2}{|c|}{$56.36(26.81)$} & \multicolumn{2}{|c|}{$73.82(34.60)$} & \multicolumn{2}{|c|}{$64.35(31.53)$} & & \\
\hline Miscellaneous cost & 2.79 & 2.25 & 2.90 & 3.44 & 4.33 & 4.37 & 3.34 & 3.35 \\
\hline (V3) & $(1.31)$ & $(1.10)$ & $(1.38)$ & (1.74) & $(2.00)$ & $(2.08)$ & $(1.57)$ & $(1.64)$ \\
\hline Total variable cost & 213.29 & 204.41 & 210.48 & 197.64 & 216.36 & 210.24 & 213.38 & 204.09 \\
\hline$(\mathrm{TVC}=\mathrm{V} 1+\mathrm{V} 2+\mathrm{V} 3)$ & (89.59) & $(89.71)$ & $(88.33)$ & $(87.24)$ & $(88.92)$ & $(87.72)$ & (88.95) & $(88.22)$ \\
\hline Gross cost & 238.08 & 227.86 & 238.29 & 226.54 & 243.30 & 239.66 & 239.89 & 231.35 \\
\hline$(\mathrm{A}=\mathrm{TFC}+\mathrm{TVC})$ & $(100.00)$ & $(100.00)$ & $(100.00)$ & $(100.00)$ & $(100.00)$ & $(100.00)$ & $(100.00)$ & $(100.00)$ \\
\hline Value of dung (B) & 6.39 & 6.08 & 6.65 & 6.85 & 6.87 & 6.80 & 6.64 & 6.58 \\
\hline $\operatorname{Net} \cos t(C=A-B)$ & 231.68 & 221.78 & 231.64 & 219.68 & 236.43 & 232.87 & 233.25 & 224.78 \\
\hline Price of milk & 36.99 & 37.20 & 36.45 & 36.30 & 35.31 & 35.82 & 36.25 & 36.44 \\
\hline Average milk & 7.50 & 7.11 & 7.75 & 7.27 & 8.56 & 7.92 & 7.94 & 7.43 \\
\hline \multicolumn{9}{|l|}{ production/ animal/ day } \\
\hline Gross return (D) & 277.52 & 264.37 & 282.60 & 263.98 & 302.24 & 283.54 & 287.76 & 270.80 \\
\hline Net return (D-C) & 45.84 & 42.59 & 50.95 & 44.29 & 65.80 & 50.67 & 54.51 & 46.03 \\
\hline Cost $/$ Litre $(\mathrm{C} / \mathrm{E})$ & 30.88 & 31.21 & 29.88 & 30.21 & 27.62 & 29.42 & 29.38 & 30.25 \\
\hline Net return / litre & 6.11 & 5.99 & 6.57 & 6.09 & 7.69 & 6.40 & 6.87 & 6.19 \\
\hline
\end{tabular}

Note: (1) M-Member, NM-Non-member (2) Figures in parenthesis in the feed and fodder cost, labour cost and miscellaneous cost rows denote their respective shares in the total variable cost.

(3) Figures in parenthesis in the green fodder, dry fodder and concentrate rows denote their respective shares in the feed and fodder cost.

\section{Cost and returns of milk production - Crossbred milch cow}

Table 6 presents the cost and returns of milk production for crossbred cow. Results showed that total fixed cost and total variable cost for member households were Rs. 26.51 and Rs. 213.38 per day per animal, respectively, while in case of non-members, the corresponding figures were Rs. 27.26 and Rs. 204.09 per day per animal, respectively. This again indicates that total variable cost comprises major share in total cost. Feed and fodder cost for member and non-member households was Rs. 136.22 and Rs.
136.39 per animal per day, respectively. In case of members, labour cost and miscellaneous cost contributed $34.60 \%$ and $1.57 \%$ of total variable cost, respectively, while for non-members, the corresponding figures were accounted as $31.53 \%$ and $1.64 \%$ of total variable cost, respectively. By including all these cost components, gross cost was worked out as Rs. 239.89 per animal per day for member households and Rs. 231.35 per animal per day for non-member households. 
Table also shows that average milk production from crossbred cow was 7.94 litre per day for members and 7.43 litre per day for non-members. In case of member households, income from milk and dung of a crossbred was accounted as Rs. 287.76 per day and Rs. 6.64 per day, respectively. While for non-members, the corresponding figures were Rs. 270.80 per day and Rs. 6.558 per day, respectively. Net return per animal was higher for member groups at Rs. 6.87 per litre as compared to Rs. 6.19 per litre for non-members. Meena (2008), Devi and Jain (2011) and Tanwar et al. (2012) also found the same results. Category-wise results showed that net income per litre of milk production for small, medium and large herd size categories of member households was Rs. 6.11, Rs. 6.57 and Rs. 7.69 per animal per day, respectively. While in case of non-members, the corresponding figures were estimated as Rs. 5.99, Rs. 6.09 and Rs. 6.4 per animal per day, respectively. This implies that rearing crossbred milch cow gives higher return than that of milch buffalo and local milch cow. Moreover, income obtained by member households was relatively higher compared to the non-member households for all herd size categories. The results also showed that as number of milch animal increase, income from crossbred cow also increases.

\section{Conclusions}

The paper examining the economics of milk production among members and $\mathrm{n}$ on-members in Rajasthan indicates that except for milch buffalo, cost per litre of milk production for all type of animals was relatively lower for member households than that of non-member households. It was also observed from the results that with the increase in herd size, cost per litre of milk production decreases for both member and non-member groups. Net returns per litre of milk production was higher for members compared to the non-members and it was found to increase with the increase in herd size. A careful look of present study reveals that rearing buffalo or crossbred cow was profitable in the study area, whereas rearing local milch cow gives negative returns to the members and non-members both. Crossbred cow gives highest profit followed by buffalo and negative returns in case of local milch cow. Therefore, it is suggested to the non-members to join the self-help groups as returns per litre of milk production for members was higher than that of non-members. It is also recommended that mixed farming should be adopted in the study area to reduce cost of milk production especially in case of local milch cow where the business is already in loss. Scientific dairy farming practices should be adopted along with upgradation of the animal breeds or use of crossbred cow. Trainings can also be provided to the farmers on proper maintenance of the animals.

\section{Acknowledgements}

This paper is part of the study conducted by the author for partial fulfillment of the Ph.D. degree program in Agricultural Economics from ICAR-National Dairy Research Institute, Karnal, Haryana. The title of thesis is 'Performance of women dairy self- help groups and its impact on socio-economic status of members in Rajasthan'. The author is grateful to the institute for giving financial help during the degree program.

\section{References}

Awasthi PK, D Rathi, V Sahu (2001) Working and Impact of Self-Help Groups on Economic Status of Women in Watershed Area of Madhya Pradesh. Indian J Agric Econ 56: 475-476

Borbora S, Mahanta R (2001) Micro-Finance through Self-Help Groups and its impact: a case of RGVN-CSP in Assam. Indian J Agric Econ 56: 449

Devi G, Jain DK (2011) Economic impact of micro-finance: a comparative study of dairy Self-Help Groups in Jaipur District of Rajasthan. Indian J Agric Econ 66: 606-618

Desai V (2005) An economic analysis of milk production and disposal pattern of milk in rural area of Bidar district (Karnataka). M.Sc. Thesis submitted to National Dairy Research Institute (Deemed University), Karnal, Haryana.

GOI (Government of India) (2019) 20 $0^{\text {th }}$ Livestock Census of India. Ministry of Agriculture, Department of Animal Husbandry and Dairying, New Delhi

GOI (Government of India) (2020) Economic Survey: 2019-20. Ministry of Finance, New Delhi

Government of Rajasthan (2018) Administrative report 2017-18. Directorate Animal Husbandry, Jaipur

Jagannath P, Singh S (2014) Centre for Microfinance: 2013-14. Report No. 7. Retrieved from http://cmfraj.org/cmfdownloads.html

Madheswaran S, and Dharmadhikary A(2001) Empowering women through Self-Help Groups: Lessons from Maharashtra rural credit project. Indian J Agric Econ 56: 427-443

Mankar GM (2003) Economics of milk production and disposal pattern in Wardha district of Maharastra. M.Sc. Thesis submitted to National Dairy Research Institute (Deemed University), Karnal, Haryana

Meena GL (2008) Impact of dairy cooperatives on the economy of rural households in Alwar district of Rajasthan. Ph.D. Thesis submitted to National Dairy Research Institute (Deemed University), Karnal, Haryana.

Mian RU, Fatema J, Rahman H (2007) Impact of dairy farming on livelihood of participating women under Grameena Bank in selected area of Rangpur district in Bangladesh. Indian J Agric Econ 62: 259-271

NABARD (2019) Status of microfinance in India: 2018-19. National Bank for Agricultural and Rural Development, Micro Credit Innovations Department, Mumbai Retrieved from https:// www.nabard.org/a u th/writereaddata/tender/ 1207192354SMFI\%202018-19.pdf

Puhazhendi V, Badatya KC (2002) SHG-Bank Linkage Programme - An impact assesment. Paper presented at the seminar on SHG-Bank Linkage Programme, New Delhi

Rajasthan Grameen Aajeevika Vikas Parishad (RAJEEVIKA), Retrieved from http://www.rgavp.org/.

Sirohi S, Bardhan D, Chand P (2015) Costs and returns in milk production: Developing standardized methodology and estimates for various production systems. Project Report submitted to Department of Animal Husbandry, Dairying and Fisheries, Ministry of Agriculture, Government of India, New Delhi

Tanwar PS, Kumar Y, Sankhala G (2012) Economics of milk production among member and non-member families of dairy co-operatives in Jaipur, Rajasthan. Indian J Dairy Sci 65: 405-409 